APSA Council in April this year that the program has not been expanded since it was created in 1984 and that maximum award amounts now appear inadequate to research. The Council consequently has authorized increasing the grant program budget to $\$ 18,000$ and increasing maximum award sizes to $\$ 1800$. The Executive Director was given the authority to cap the competition at $\$ 15,000$ if mid-fiscal year budget information indicates the Association is facing a deficit.

The Research Support Committee is chaired by John Sprague, Washington University, and includes Charles W. Harris, Howard University; Margaret P. Karns, University of Dayton; Karen O'Connor, Emory University; Herbert Asher, Ohio University; and Marion Just, Wellesley College.

The grant recipients for 1995 and their projects are the following.

Douglas Blum, Providence College, "Russian Environmental Security Policy in the Caspian Sea: International Relations, Domestic Politics, and State Interests"

Maureen H. Casamayou, Mount Vernon College, "Nice Girls No More: Grassroots Empowerment and the Politics of Breast Cancer"

Ting Gong, Ramapo College of New Jersey, "From Revolutionary Cadres to Business Elites in China's Reform Era"'

John C. Hickman, Berry College, "The Effects of District Magnitude on the Representation of Women in Japanese Prefectural and Municipal Assemblies"

Febrice E. Lehoucq, Christopher Newport University, "The Electoral Bases of Public Expenditures in Guatemala"'

Tracy Lightcap, Lagrange College, "Issues in the Measurement of Judicial Attitudes"

Stephen V. Monsma, Pepperdine University, "Church and State in Five Democracies" (Joint Proposal with J. Christopher Soper)

Carol Nechemias, Pennsylvania State University of Harrisburg,
"The Women of Russia Movement: Year One in the Russian Duma"

Suzanne U. Samuels, Seton Hall University, "A Study of the Impact of U.A.W. v. Johnson Controls on the Equal Employment Opportunity Commission and the Occupational Safety and Health Administration"

Denise L. Scheberle, University of Wisconsin-Green Bay, "Working Together or Pulling Apart: State and Federal Relationships in Environmental Programs"

J. Christopher Soper, Pepperdine University, "Church and State in Five Democracies" (Joint Proposal with Stephen V. Monsma)

Nayda Terkildsen, Drew University, "Mass Media Coverage of the Women's Movement."

If you would like more information on APSA's research grants or have suggestions for the committee, please contact Michael Brintnall at APSA. The 1996 competition will be announced in the December issue of $P S$.

\section{APSA Minority Identification Project}

The American Political Science Association, led by some of our leading graduate schools, has made a major commitment to increase the numbers of minority students attending doctoral programs in political science and entering our profession.

Personal contact between faculty and student is at the heart of the program through group meetings, personal advising, involving students in faculty research, and other mentoring.

Also, APSA operates a clearinghouse of names of minority students referred by faculty for graduate study, by circulating the names referred by undergraduate faculty to graduate schools. Graduate schools recruit students identified in this process by personal contacts, waivers of application fees, and expedited financial aid consideration. APSA also writes to each student with information about political science careers.
If you would like to participate, please plan to talk with students about a career in political science, and let APSA know the names of promising minority candidates for Ph.D. study. Even the name of just one student will be an important contribution to the project. Please call, fax, email or send the following information about each student as early in the fall as possible.

1) name and address;

2) GPA (or your best estimate);

3) year of graduation;

4) race/ethnicity; and

5) a brief comment relevant to consideration for graduate school.

Send the information to: Michael Brintnall, Director of Professional Affairs, APSA 1527 New Hampshire Avenue, NW, Washington, DC 20036, (202) 483-2512; fax: (202) 483-2657; brintnall@apsa. dgsys.com.

\section{Section News}

\section{Political Methodology Section List-Serve and World-Wide Web Site}

The Political Methodology Section of APSA now has a list-server (also available as a digest) and a World-Wide Web site based at the University of California-Riverside. They are funded in part by a grant from NSF to the political science department at UC-Riverside.

The list-server for Political Methodology serves as a forum for discussion of political methodology. Topics discussed recently have included questions of software use, statistical issues, questions of replication, etc. It is also to announce conferences, to circulate abstracts, and will no doubt be put to as yet undiscovered purposes. It is an unmoderated list. To contribute anything, simply send your message to: polmeth@wizard.ucr.edu.

To subscribe, send a message with the following text to polmethrequest@wizard.ucr.edu: subscribe $<$ your e-mail address >.

The World-Wide Web site of the Political Methodology Section is 
used to make available conference papers, working papers, previous issues of The Political Methodologist, programs for upcoming meetings, and other news. It includes links to sites with software and data available has instructions for uploading and downloading papers, and allows you to read abstracts on-line. It is the hub in cyberspace where political methodologists hang out; a virtual Mos Eisley Cantina for political methodologists.

You can get there by pointing your web-browser at: http://wizard. ucr.edu/polmeth/polmeth.html.
Both the list-server and the website are administered by Jonathan Nagler. If you have any questions, comments, or suggestions, please send e-mail to nagler@wizard. ucr.edu.

INTERNATIONAL POLITICAL SCIENCE ASSOCIATION

\section{INTERNATIONAL POLITICAL SCIENCE ABSTRACTS DOCUMENTATION POLITIQUE INTERNATIONALE} 27, rue Saint-Guillaume, 75337 PARIS CEDEX 07, FRANCE

$$
\text { Fax : (33) (1) } 42223964
$$

Published since 1951 by the International Political Science Association (all back volumes are available), the Abstracts is a major source of bibliographic information in political science. It publishes abstracts of articles in specialized and non specialized periodicals, including major yearbooks. Articles in English are abstracted in English; those in other languages (about one fourth of the total) are abstracted in French, with all titles translated into English. In 1994 it published 6,397 abstracts from over 1,000 journals, in six issues. Each issue carries a detailed subject index and a list of the periodicals examined. The final issue of each volume provides a cumulative subject index and an author Index.

\section{SPECIAL INTRODUCTORY OFFER TWO YEARS AT HALF PRICE WITH ONE ADDITIONAL YEAR FREE FREE EXAMINATION COPY}

For volumes 44 (1994) and 45 (1995), new institutional subscribers are granted a 50 percent reduction, and pay only US $\$ 181$ per volume, instead of approximately US \$ 363 (the equivalent of French francs 1,925). Payment may be made for volume 45 only, or for both volumes 44 and 45 . On request, new subscribers will receive all issues of volume 43 (1993) as an introductory present. Do not hesitate to request a free examination copy.

\section{NOW ALSO AVAILABLE ON CD-ROM}

International Political Science Abstracts on CD-Rom contains 36,000 records initially. Coverage is from 1989 until present. The database will be updated three times a year.

Publisher : SilverPlatter Information B.V. Nieuwe Herengracht 49

NL-1011 RN Amsterdam, The Netherlands

tel: +31206259650 tax : +31206237408

The above prices are for stand alone subscriptions: for networking prices please call SilverPlatter. A $50 \%$ discount is available for end-users in developing countries.

For the above mentioned prices you will receive: a yearly subscription to International Political Science Abstracts on CD-Rom with three updates; SilverPlatter retrieval soltware for the DOS, Macintosh or Windows environment with installation manual. 